\title{
Leverage of Learning Science through Blended Learning Technique
}

\author{
S. Selvakumar, P. Sivakumar, R. Daphine
}

\begin{abstract}
Digitalization in education is becoming a standard for $21^{\text {st }}$ century's pedagogical contexts. Blended learning presents new learning situation based on technology for learners, thus requiring diverse research for establishing effective teachinglearning. The present study aims to find out the effectiveness of adopting a blended learning technique in learning science course at the high school level. A quasi-experimental design has been applied for the present research work. This research work used an intact class of 60 high school students treated as the sample. The tools adopted for data collection were the Science Achievement Test (SAT) and Blended Learning Technique (BLT). For four weeks, the learners in the experimental group were taught with the blended learning technique, while the control group was treated with the traditional learning technique. Two groups were administered the three tests such as pre-test, post-test I and post-test-II. The analyzed data and findings revealed that the significant differences between the mean scores of control and experimental groups. The study concluded that blended learning significantly improves learner's achievement in science and retention ability. It is recommended to adopt blended learning technique as it enhances the learner's academic achievement and retention.
\end{abstract}

Keywords: Blended learning technique, Traditional learning technique, Academic achievement, Retention ability, Learning achievement.

\section{INTRODUCTION}

Science and technology have always been instrumental in bringing efficiency and improvement in all aspects of human work. The notable difference between the science and technology is that the science ascertains a principle or creates a theory based on experimentation while the technology utilizes that the principle or theory for upgrading the existing facilities and practices. Education in a country is an important key indicator of its development (UNESCO2005). In the Indian context, the ICT in education is in a budding stage. There are many advantages to utilizing ICT in the pedagogical process. There are no longer geographical boundaries for learning new concepts without any restrictions like time, place, and pace [1]. More rights and opportunities are given for learners to choose the pertinent path of education. The widespread use of the Internet and online technologies in the education arena and a chance for mixing traditional teaching with online instruction indicate a change in the way of disseminating instruction to the learners as well.

Revised Manuscript Received on April 25, 2020.

* Correspondence Author

Mr. S. Selvakumar*, PhD. Research Scholar, Department of Education (DDE), Alagappa University, Karaikudi, Tamil Nadu, India.

Prof. P.Sivakumar, Professor \& Head, Department of Education (DDE), Alagappa University, Karaikudi, Tamil Nadu, India.

Dr. R. Daphine, Assistant Professor \& Head, Department of PhysicsUG SF. The American College, Madurai, Tamil Nadu, India.

(c) The Authors. Published by Blue Eyes Intelligence Engineering and Sciences Publication (BEIESP). This is an open access article under the CC BY-NC-ND license (http://creativecommons.org/licenses/by-nc-nd/4.0/)
An important implication of this transition is the need for the employment innovative pedagogies and appropriate technologies [2]. One of the ideal learning environments is Blended Learning in which the blending is in accordance with the need of the learners, nature of the subject matter and even based on the availability of ICT infrastructural facilities. Hence, the current study intended to identify the impact of Blended Learning technique in learning science at the high school level.

\section{A. Blended Learning Technique}

The ICT infrastructure heaps in educational sectors has been the foremost preferable precedencies of educational policies during the last two decades. The rapid growth of ICTs providing various features and tools has encouraged researchers \& teachers to design an interesting learning environment for learners [3]. Most of the developing and developed countries have invested considerable amounts of public resources in ICT equipment. When the researchers, teachers and administrators initiated to use the online technologies in the educational context, the two varieties of teaching-learning techniques, such as traditional classroom-based, and distance learning approaches remained mostly distinct because they used a variety of approaches or media of combinations in accordance with their learners. Presently a wide range of methods of teaching and as well as learning which integrate the utilization of ICT with the class-room based on Kern and Warschauer [4] noted that change from learners interacting with their computers to interacting with other human beings through their computer is an important factor. Thus, in terms of providing the learner-instructor and learner-learner interactions, and to minimize the isolation from other learners force, the teachers and researchers to find out an idea for the models of teaching which is offered to their learners. Subsequently, the need for a combination between the classroom-based and online learning approaches or techniques leads the educators towards a new approach or technique in teaching and as well as in learning. This new technique is known as "Hybrid Learning (HL) or Blended Learning (BL)" [5].

Blended learning is an educational model that unites varieties of learning strategies [6]. The concept of Blended Learning (BL) has a wider scope. Besides, Driscoll [7] summarizes the four types of concepts on BL

1. BL is a mixing the various modes of Web-based technology (for instance streaming video, audio and text, virtual classroom, etc.,) to fulfill the predetermined educational goals.

2. BL is a combination of different pedagogical approaches (for instance behaviorism, constructivism etc.,) to deliver desirable learning outcome. 


\section{Leverage of Learning Science through Blended Learning Technique}

3. BL is a combination of different forms of instructional technology (for instance CD-ROM, videotape, film etc.,) with the regular classroom teaching.

4. $\mathrm{BL}$ is a combination of different instructional technology with actual job tasks to generate a congenial effect of learning and for working.

Blended Learning is a derivative of two different words, such as 'blend' and 'learning'. The term blend denotes merging things and learning indicates as a process of gaining desirable knowledge. Osguthrope and Graham [8] suggested that $\mathrm{BL}$ is a combination of class-room teaching with distance mode of delivery systems. According to them it is not just showing a page from a Website in the classroom. It is based on various teaching methodologiespedagogies to satisfy the needs of learners. Blended Learning Environment (BLE) is to utilize the maximum benefits of both classroom teaching and online mode. In BLE some important parts of learning activities are shifted to a web-based environment and thereby the time spent in the classroom would be decreased [9]. Johannes C Cronje, [10] suggested that a definition of BL must include context, theory, method and technology because the author insisted that blended learning is a proper utilization of a combination of theories, methods and technologies to establish optimized learning in a particular context. Thus, Blended learning is the combination of multiple techniques in learning, including ICT based practices, pedagogies and traditional classroom instructions to enhance learning. Based on the above definitions the following key features of Blended learning are identified;

i) BL is also known as Hybrid learning (HL). It is an ideal collaboration of class-room learning and webbased learning techniques.

ii) The new way of mixing different modes of Webbased technology with various pedagogical approaches brings an optimal learning outcome.

iii) BL combines classroom teaching with various technology-based learning systems.

iv) In this unique technique, some important parts of learning activities are shifted to a web-based environment and thereby the time spent in the classroom would be decreased.

v) $\mathrm{BL}$ is proper utilization of a combination of theories, methods and technologies to establish optimized learning in a particular context.

vi) It is a combination of multiple approaches in learning, including ICT based practices, pedagogies and traditional classroom instructions to enhance learning.

\section{B. The intention of the study:}

The present study intends to ascertain whether any significant difference exists in the Blended Learning Technique (BLT) compared to Traditional Learning Technique (TLT), assessed by student achievement scores in Science at high school level.

\section{Research Questions and Hypotheses:}

In line with the research objectives, the study had the following research questions and hypotheses:-
1. What is the difference in the mean scores of post-test I between experimental group and control group in learning science?

$\mathbf{H}_{\mathbf{0}} \mathbf{1}$ : There exists no significance of difference in the mean scores of post-test I between experimental group and control group in learning science.

H1: There exists significance of difference in the mean scores post-test I between experimental and control groups in learning science.

2. What is the difference between mean scores of post-test I and the mean scores post-test-II in learning science?

$\mathbf{H}_{\mathbf{0}}$ 2: There exists no significance of difference between mean scores of post-test I and the mean scores post-test II in learning science.

H2: There exists significance of difference between the mean scores of post-test I and the mean scores post-test II in learning science.

3. What is the variation among mean retention ability of students in learning science based on two instructional techniques?

$\mathbf{H}_{\mathbf{0}}$ 3: There exists no significance of difference between the mean retention ability of learners in learning science on two instructional techniques.

H3: There exists a significance of difference between the mean retention ability of learners in learning science on two instructional techniques.

\section{METHODOLOGY}

\section{A. Research Design}

The objective of the present study is to explore the effectiveness of adopting a Blended Learning Technique (BLT) in learning Science course. The present study adopted the quantitative method where descriptive statistical procedures are applied for exploring the comparative effectiveness of blended learning technique and the traditional learning technique. The Quasi-experimental research method and pre and post tests control group design was adopted to verify the efficacy of blended learning technique in learning science.

The design is represented schematically as follows:

$\mathrm{O}_{1} \mathrm{X}_{1} \mathrm{O}_{3} \mathrm{O}_{5}$ Experimental Method (BLT)

$\mathrm{O}_{2} \quad \mathrm{X}_{2} \mathrm{O}_{4} \mathrm{O}_{6}$ Conventional Method (TLT)

The $\mathrm{O}_{1}$ is the pre-test scores of the experimental group, $\mathrm{O}_{2}$ is the pre-test scores of the control group. Similarly, $\mathrm{O}_{3}$ and $\mathrm{O}_{4}$ are the post-test- $\mathrm{I}$ and $\mathrm{O}_{5}$ and $\mathrm{O}_{6}$ are posttest-II scores of experimental and control groups. $\mathrm{X}_{1}$ is BLT and $X_{2}$ is TLT. The independent variables in this research are blended learning and traditional learning techniques and the dependent variable is the academic achievement in learning science. 


\section{B. Participants}

The researchers have chosen a sample for the study by using purposive sampling technique from a School, located at Karaikudi. A total sample of sixty from ninth standard was selected based on their percentage of marks secured in their previous examination and formed a homogenous group. Further, these sixty were divided equally using simple random sampling technique into groups namely the experimental group and control group and both groups consisted of thirty students each. For the experimental group, Blended Learning Technique (BLT) was followed whereas for the control group, the Traditional Learning Technique (TLT) namely lecture method was adopted.

\section{Tools and data collection}

To explore the research questions, the investigator selected the unit namely 'Gravitation' and 'Heat' in the Science textbook for $9^{\text {th }}$ standard new syllabus prescribed by the Government of Tamil Nadu. Lessons under the selected units are carefully analyzed for the development of appropriate learning objectives. Opinions and ideas of experienced teachers and teacher educators are carefully considered while framing the learning objectives. Then the researchers developed the Blended Learning Technique (BLT) for each lesson along with different activities and appropriate audio and video files. The developed packages were handed over to the subject experts, technical experts and experienced teachers. Based on their recommendations, some modifications were carried out in the BLT package. Then, the researchers developed a Science Achievement Test (SAT) to identify the academic achievement level among the learners, the SAT consisted of 25 questions of multiple choice. Based on Cronbach Alpha the reliability of the SAT was established. The Cronbach Alpha was 0.87.

The data was collected based on the procedure of classroom-based research which is considered of planning, action, observation and reflection [11]. This research study conducted in four weeks. The pre-test was administered at the beginning of the treatment to both experimental and control groups. Then, researchers conducted the BLT on experimental group and TLT on control group for four weeks. At the final day of the treatment, experimental and control groups participants were responded to the post-test-I. After a month of the treatment, post-test-II was conducted for both groups to determine the retention level of participants.

\section{Data analysis:}

The collected data were analyzed in quantitatively. The participants' scores in the pre-test, post-test-I and posttest-II were analyzed in SPSS. All the hypotheses were tested at the 0.95 confidence interval. The researchers used the descriptive analysis (Mean \& SD) and differential analysis (t-test) computed for the results of both groups to analyze differences between the pre and post-tests.

\section{FINDINGS}

\section{A. Results}

To determine the homogeneity of experimental and control groups, the significance of differences between the mean values of pre-test scores of the groups are computed by using t-test. The results are shown in table (1),

Table 1: t-test analysis on the mean difference between pre-test scores of the experimental and control groups

\begin{tabular}{|c|c|c|c|c|c|}
\hline Group & N & Mean & SD & t & P \\
\hline Experimental & 30 & 41.57 & 1.995 & \multirow{2}{*}{0.3219} & 0.7487 \\
\cline { 1 - 4 } Control & 30 & 41.40 & 2.094 & & \\
\hline
\end{tabular}

The t-test analysis on the difference in the pre-test mean scores of both experimental and control groups are 41.57 and 41.40 with standard deviation 1.995 and 2.094 respectively. The $\mathrm{P}$-value 0.7487 was greater than the alpha value of 0.05 . The results revealed that there is no statistically significant difference between mean values of participants of experimental and control groups in the pretest. Hence, the homogeneity of the groups is well determined before the treatment of this research.

\section{B. Results on Hypotheses:}

RQ1: What is the difference in the post-test I mean scores between experimental and control groups in learning science at high school learners?

Table 2: t-test analysis on the mean difference in the post-test-I mean scores of experimental and control groups

\begin{tabular}{|c|c|c|c|c|c|}
\hline Group & $\mathbf{N}$ & Mean & SD & t & P \\
\hline $\begin{array}{c}\text { Experi- } \\
\text { mental }\end{array}$ & 30 & 57.67 & 1.90 & \multirow{2}{*}{12.247} & 0.0001 \\
\hline Control & 30 & 50.50 & 2.25 & & \\
\hline
\end{tabular}

The t-test analysis on the difference in the post-test I mean scores of experimental group 57.67and control group was 50.50 with a standard deviation of 1.90 and 2.25 respectively. The p-value of 0.0001 was less than 0.05 level of significant, therefore the study shows that significant difference exists in the post-test I mean scores between experimental and control groups. The null hypothesis is rejected.

RQ2: What is the difference between post-test I and post-test-II mean scores in learning science at high school learners?

Table 3: t-test analysis on the mean difference between post-test I and post-test II mean scores of the experimental group

\begin{tabular}{|c|c|c|c|c|c|}
\hline $\begin{array}{c}\text { Achievement } \\
\text { Test }\end{array}$ & N & Mean & SD & t & P \\
\hline Post-test I & 30 & 57.67 & 1.9 & 2.3435 & 0.0622 \\
\hline Post-test II & 30 & 56.47 & 2.063 & & \\
\hline
\end{tabular}

The analysis of difference the retention ability of learners learned science using Blended learning technique shows the

Published By: 
post-test I mean score of 57.67 with a standard deviation of 1.9. The post-test-II mean score was 56.47 with standard deviation of 2.063. The probability value of 0.0622 obtained was greater than the alpha value of 0.05 . The analysis, therefore, shows that no difference in the post-test I and post-test II mean performance of students learned science using BLA. The null hypothesis is accepted.

RO3: What is the difference between the mean retention ability students in learning science-based on two instructional techniques in high school learners?

Table 4: t-test analysis of the difference in mean retention ability of learners in learning science based on two instructional techniques

\begin{tabular}{|c|c|c|c|c|c|}
\hline Variables & $\mathbf{N}$ & Mean & SD & t & P \\
\hline TLT & 30 & 44.80 & 3.295 & \multirow{2}{*}{16.442} & \multirow{2}{*}{0.0001} \\
\hline BLT & 30 & 56.47 & 2.063 & & \\
\hline
\end{tabular}

The t-test analysis used to conclude the difference in the post-test II exposed the mean score of 44.80 with standard deviation 3.295 for students in the TLT. Students in BLT had a mean score of 56.47 with standard deviation of 2.063. The $p$-value was less than the alpha value $(\mathrm{P}=0.0001$ $<0.05)$. The analysis therefore shows that significant difference exists in the post-test II mean performance of two groups of students; hence the null hypothesis was rejected.

\section{Discussion}

The research study aimed to investigate the efficacy of adopting a Blended Learning technique in learning of Science at high school learners. The result of the pre-test mean score in table (1) shows that there is no significant difference $[\mathrm{P}=0.7487>0.05]$ between both experimental and control groups. Hence, the homogeneity of the group was established. A similar result was also found by Sivakumar and Selvakumar [12] which shows that there was no significant difference between experimental and control groups. The t-test analysis from the table (2) on the difference in the post-test-I mean values between experimental group and control group significantly differs $[\mathrm{P}=0.0001<0.05]$. It has been concluded that post-test-I mean score of the experimental group is statistically higher than the control group post-test-I mean scores. The finding indicated that BLT is effective than the TLT. This finding agreed with that of Dina Rahmah Maulida, Suparwoto, Yudhiakto Pramudya \& Dwi Sulsworo [13], Ibrahim [14], Sivakumar [15], Tyas, Muam, Sari \& Dewantara [16] and Selvakumar \& Sivakumar [17] who reported that blended learning strategy is effective on students' academic achievement.

The study further revealed that based on the table (3), there was no significant difference in post-test-I and post-test-II retention ability of high school students when BLT was adopted. From the analysis, the mean values of participants in post-test-I were 57.67 with standard deviation 1.9 while that of post-test-II was 56.47 with standard deviation 2.063. The probability value 0.0622 obtained indicated there is no significant difference $[\mathrm{P}=0.0622>$ 0.05] between post-test-I and post-test-II mean retention performance of high school students learning science. The analysis of table (4) indicated that the use of BLT improved the retention ability of students in learning science at the high school level. The mean retention of participants in the experimental group was 56.47 with standard deviation 2.063 against 44.80 and 3.295 for control group participants respectively. The probability value of 0.0001 obtained indicated that a significant difference exists in the retention ability of the two groups' participants. Based on the above two findings, it is found that BLT is more effective on retention performance of participants than TLT. It is consistent with the studies of Sivakumar \& Selvakumar [12], Ibrahim \& Haruna [18].

\section{CONCLUSIONAND RECOMMENDATIONS}

Based on the results and discussion described in the previous section, the research clearly showed that the performance and retention ability of high school students in learning science was better in blended learning compared to traditional learning. The study findings encourage the high school teachers to utilize blended learning techniques as it enhanced the students' academic achievement and retention. Further, the findings of this study impulse preparing prospective teachers should have adequate training to use novel instructional strategies such as blended learning strategy. Hence, it is recommended that adequate competencies should be developed among prospective teachers to adopt Blended Learning strategies. The teacher educators should identify the various components of Blended learning competencies and once such competencies are identified it is possible to find out the ways and means of developing the competencies. Moreover, based on findings, it is recommended to establish adequate technology infrastructure like modern ICT devices and high-end internet services to help teachers to develop the indigenous materials on blended learning.

\section{ACKNOWLEDGEMENT}

This article has been written with the financial support of RUSA-Phase 2.0 grant sanctioned vide Letter No. F.24-5112014-U, Policy (TN Multi-Gen), Dept. of Edn., Govt. of India, Dt.09.10.2018.

\section{REFERENCES}

1 Arulsamy S., and Sivakumar P., "Applying Quality in Higher Education", Edutracks,

KAIZEN for Neelkamal Publications, New Delhi,2005.

2 Rovai, A. P., \& Jordan, H. M. "Blended learning and sense of community: A comparative analysis with traditional and fully online graduate courses". The International Review of Research in Open and Distance Learning, 2004.

3 Selvakumar, S., \& Sivakumar, P. "Learning outcomes and challenges in Blended learning", Shanlax International Journal of Arts, Science and Humanities $\quad$ ISSN: 2321-788X Pp. 210-218, 2017, 5(1).

4 Kern, R., \& Warschauer, M. "Theory and practice of network-based language teaching". In M. Warschauer \& R. Kern (Eds.), Network-based language teaching, 2000.

Blue Eyes Intelligence Engineering

\& Sciences Publication 
5 Rogers, P. L., Traditions to transformations: The forced evolution of higher education. Educational Technology Review, 9(1), 47-60,2001.

6 Bonk CJ, Graham CR "The handbook of blended learning: Global perspective, local designs". San Francisco, CA: Pfeiffer Publishing, 2005.

7 Driscoll, M. Blended learning: Let's get beyond the hype. Elearning, 3(3), 56, 2002.

8 [Osguthorpe R. T., \& Graham, C. R. Blended Learning Environments Definitions and Directions. The Quarterly Review of Distance Education, 4(3), 2003.

9 Garnham, C., \& Kaleta, R. Introduction to hybrid courses. Teaching With Technology Today, 8 (6). Retrieved from http://www.uwsa.edu/htttp:/articles/garnham.html, 2002.

10 Johannes C Cronje. Towards a new definition of Blended Learning, E Journal of E learning, 18(2), 2020.

11 Kemmis, S., McTaggart, R., \& Nixon, R. The action research planner: Doing critical participatory action research. Springer Science \& Business Media, 2013.

12 Sivakumar, P \& Selvakumar, S. "Blended Learning Package: It's Effectiveness on Students' Performance and Retention in Higher Secondary Physics Course" International Journal of Scientific \& Technology Research, Pp. 1316-1320, ISSN: 2277-8616, 8(10), 2019.

13 Dina, R. M., Sulisworo, D., Suparwoto, S., \& Yudhiakto, P. Embedding The Guided Inquiry On Blended Learning To Enhance Conceptual Understanding. International Journal of Scientific \& Technology Research, 9(1), 1480-1485,2020.

14 Ibrahim, A. Y. Effect of blended learning on students' achievement in senior secondary geography in niger state, Nigeria. e-Academia Journal, 8(1), 2020

15 Sivakumar P. "Effectiveness of Blended Learning in Teacher Education Programme through Distance Mode", Proc. International Conference on Distance Learning, Research and innovation for a Digital Society, STOU, \& UNESCO Bangkok, Thailand, Pp.151159. Aug. 2019.

16 Tyas, A. S. P., Muam, A., Sari, Y. I. H., \& Dewantara, C. The Effectiveness of Blended Learning in Improving Students' Workplace Communication Skills: A Case Study on Olive Website Test Result. Lingua Cultura, 14(1), 2020.

17 Selvakumar, S., \&Sivakumar, P. "The Impact of Blended Learning Environment on Academic Achievement of Engineering Students" International Journal of Innovative Technology and Exploring Engineering, Pp.3782-3787, DOI: 10.35940/ijitee.L3825.1081219, ISSN: 2278-3075, 8(12, 2019.

18 Ibrahim, A., \& Haruna, J. A. "Effects of flipped and

19 conventional teaching approaches on performance and retention ability of students in advance financial accounting" in Abubakar Tafawa Balewa university Bauchi, Nigeria. Jurnal Psikologi Malaysia, 31(2), 20.

\section{AUTHORS PROFILE}

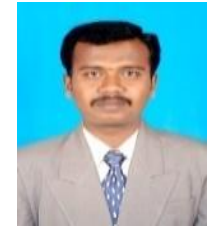

Mr. S. Selvakumar is a $\mathrm{PhD}$ Research Scholar in Education pursuing his research under the guidance of Prof. P. Sivakumar in the Department of Education (DDE) at Alagappa University, Karaikudi, Tamil Nadu, India. He obtained his Bachelor Degree of Education and Master Degree of Education at Alagappa University, Karaikudi, Tamil Nadu, India and NET qualified in Education. His $\mathrm{PhD}$ research focuses on the effectiveness of Blended learning in Science education. He presented 10 papers in national/ international level seminars and conferences. Further, he published 5 articles in national and international journals. He attended and presented a research paper at the International Conference in Singapore. He is a lifetime member of Association for Development of Teaching, Education and Learning (ADTEL). (e-mail-selvaphdedu@gmail.com).

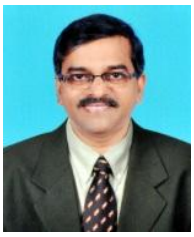

Prof. P. Sivakumar is a professor and Head in the Department of Education (DDE), Alagappa University, Karaikudi, Tamil Nadu, India. His field of expertise is Educational technology, Biology Education, Curriculum Development. He is the recipient of NCERT Award for innovation in teacher education from NCERT, New Delhi and Bharat Gaurav Award for his outstanding contributions in the field of education, research and innovation. He has

Published By:

Blue Eyes Intelligence Engineering \& Sciences Publication (C) Copyright: All rights reserved. presented more than 30 research papers in the International conferences/ seminars and 45 research papers in the national seminars/conferences. He has published more than 52 research articles in the National /International level journals. Under his guidance, $14 \mathrm{PhDs}$ and more than 32 M.Phil. degrees have been awarded and currently $8 \mathrm{PhDs}$ pursuing research in the broad field of educational technology. He has been served as a member of Board of Studies in various leading universities across Tamil Nadu. He is also a life time member of Society for Educational Technology, Research and Development, International Association of Educators for World Peace (IAEWP), The Indian Science Congress Association, Indian Society for Education and Allied Sciences, Indian Association of Teacher Educators (IATE), and Association for Development of Teaching, Education and Learning (ADTEL). He has served as a Dean- Faculty of Education and Director i/c, Directorate of Distance Education in Alagappa University, Karaikudi. He also served as Director i/c. of Center for Distance Education and founder Professor and Head of the Department of Education, CDE in Bharathidasan University, Trichy. He is well known for his contribution in the area of Educational Technology, Biology Education and Curriculum Development. For academic purpose, he visited Singapore, France, Thailand and Malaysia. (E-mail: psksiva2002@gmail.com/ Website: sivakumareducation.com)

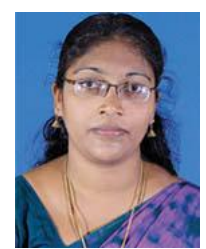

Dr. R. Daphine is working as an Assistant Professor in the Department of Physics and Heading the undergraduate self-financed programme in Physics at the American College, Madurai. She also has wide experience as a Teacher Educator. She has worked nearly seven years in the Teacher Education field. Her area of research is Technology integration in physics evaluation. She has published around five articles in International journals and seven in National journals and has presented 20 papers in many International and National conferences and Workshops. She has visited Singapore and presented a paper in the International Conference, which was funded by UGC, under Travel Grant scheme in the year-2017. (Email:daphinedaniel@gmail.com) 